\title{
p-Aminobenzoate Organic Salts as Potential Plant Growth Regulators for Tomatoes
}

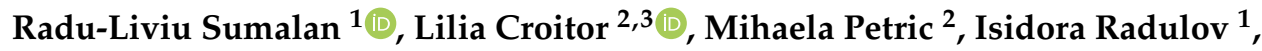 \\ Paulina Bourosh ${ }^{3}$, Renata-Maria Sumalan ${ }^{1}$ (D) and Manuela Crisan ${ }^{2, * \mathbb{D}}$ \\ 1 Faculty of Horticulture and Forestry, Banat's University of Agriculture Science and Veterinary Medicine \\ “King Michael Ist of Romania" from Timisoara, Calea Aradului nr 119, 300645, Timisoara, Romania; \\ sumalanagro@yahoo.com (R.-L.S.); isidoraradulov@yahoo.com (I.R.); srenata_maria@yahoo.com (R.-M.S.) \\ 2 “Coriolan Dragulescu" Institute of Chemistry, 24 Mihai Viteazul Blvd., 300223, Timisoara, Romania; \\ croitor.lilia@gmail.com (L.C.); mihaelapetric@yahoo.com (M.P.) \\ 3 Institute of Applied Physics, Academiei Street 5, MD2028, Chisinau, Moldova; bourosh.xray@phys.asm.md \\ * Correspondence: mdorosencu@yahoo.com; Tel.: +40-256-491818
}

Academic Editor: Mai Antonello

Received: 14 March 2020; Accepted: 31 March 2020; Published: 2 April 2020

check for updates

\begin{abstract}
The discovery of environmentally friendly and inexpensive plant growth regulators (PGRs) for agronomically important crops is a necessity and must be considered a priority worldwide. This study provides the synthesis, structure determination and the biological evaluation of two binary organic salts as potential PGRs. New compounds have dual biological activity and are based on natural metabolite $p$-aminobenzoic acid $(p \mathrm{ABAH})$ and different alkanolamines. Studied compounds exhibit hydrogen-bonded 3D supramolecular architectures with different crystal packing due to the formation of one homosynthon and various heterosynthons. The biological profile of new compounds was investigated in laboratory and greenhouse on Solanum lycopersicum L., revealing the efficiency in promoting plant rooting and plant productivity. The results may have a positive impact on agricultural economics, developing new sustainable PGRs for tomatoes.
\end{abstract}

Keywords: $p$-aminobenzoic acid; alkanolammonium salt; biological activity; plant growth regulator; crystal structure; supramolecular assembly

\section{Introduction}

Growing populations have imposed the use of plant growth regulators (PGRs), which have become an integral part of agricultural and horticultural practices, maximizing crop production. To mitigate the harmful effects of conventional synthetic PGRs, such as 2,4-dichlorophenoxyacetic acid-2,4-D, on the environment and plant health [1], extensive efforts have been devoted to discovering sustainable alternatives. Since natural compounds extracted from plants or produced by bacteria rapidly degrade, limiting the applicability of the product [2], the use of PGRs based on synthetic analogues of natural products or active pharmaceutical ingredients commercially available are considered to be more effective [3]. Therefore, developing innovative, environmentally friendly and cost competitive PGRs remains an important task for researchers and a necessity at the global level for nutrition security. Understanding of chemical and crystal structure, inter- and intramolecular interactions as well as the structure-biological activity relationship is essential for investigation of new PGRs. Extensive studies show the importance of the carboxyl group and the planar aromatic ring in the structure of auxin-like PGRs, essential molecules that control almost every aspect of dormancy, seed germination and plant development [4].

Thus, benzoic acids, well-known for their importance as building blocks in drug development, gained increasing attention in plant science, being involved in various physiological processes from the 
regulation of seed germination [5-7] to disease resistance and stress tolerance in plants [8,9]. Among these compounds, $p$-aminobenzoic acid $(p \mathrm{ABAH})$ is a well-known natural metabolite present in plant and animal tissues, widely described in literature as a precursor of folic acid [10] and recently of coenzyme Q [11]. It possesses numerous biological activities in medicine such as antioxidant [12], antibacterial [13], antimutagenic [14], anticoagulant [15], fibrinolytic and immunomodulating agent [16], protective drug against UV-irradiation [17] and also in agriculture as a chemical inducer associated with thermotolerance [18] and pathogens resistance [19] in plants. Moreover, an examination of the Cambridge Structural Database (CSD) has confirmed the $p$ ABAH versatility as a fundamental building block in the design of soluble forms of organic multicomponent crystals and coordination compounds with various supramolecular architectures [20,21]. Besides being frequently used as co-formers, such as aliphatic and heterocyclic amines, alkanolamines are very few despite their lower toxicity [22], and their use as intermediates for the production of active pharmaceutical and cosmetic ingredients.

Our previous studies show the huge potential of alkanolamine-substituted benzoic acid systems which can generate supramolecular architectures with different topologies (1D, 2D and 3D) guided by different non-covalent interactions [23-25], have low toxicity [25,26], thermal stability [27] and promising applicability as auxin-like PGRs on the model plant Arabidopsis thaliana Col 0 [6]. The aim of this work was to develop new alkanolammonium $p$-aminobenzoates with characteristics of ideal PGRs: low toxicity, easily synthesized in laboratories, non-expensive, soluble in water and to investigate their role in growth and development of the most important vegetable cultivated in Romania and European Union in the last years, Solanum lycopersicum L. The discovery of new PGRs for commercial vegetables is essential, because vegetables play a vital role in food front, being the cheapest natural sources. Herein, two new alkanolammonium $p$-aminobenzoates were synthesized, structurally and physicochemically characterized and evaluated for their PGRs' activity on tomatoes (S. lycopersicum L).

\section{Results and Discussion}

The new compounds were prepared by proton exchange reaction of $p A B A H$ with different alkanolamines (HEEA- $p$ ABA-ethylethanolammonium $p$-aminobenzoate; HDEEA- $p$ ABA — diethylethanolammonium $p$-aminobenzoate) and isolated in excellent yields ( $>95 \%)$. The $\mathrm{pKa}$ rule [28] predicted the salts formation, because $\Delta \mathrm{pKa}$ values $\mathrm{pKa}$ (alkanolamine)-pKa( $p \mathrm{ABAH})$ were greater than three. Physicochemical and structural characterizations of new compounds are presented below.

\subsection{Crystallographic Study}

The single crystal X-ray diffraction data indicated that HEEA-pABA crystallizes in the monoclinic centrosymmetric $P 2_{1} / c$ space group, while HDEEA- $p$ ABA crystallizes in the orthorhombic asymmetric Pna2 1 space group (Table 1 ).

The analysis of both crystal structures revealed the formation of 1:1 organic salts HEEA- $p$ ABA and HDEEA- $p$ ABA with proton transfer from carboxylic group of $p A B A H$ to nitrogen atoms of alkanolamine molecules (Figure 1). The ( $p \mathrm{ABA})^{-}$anion formed non-planar system in HEEA- $p$ ABA and a practically planar system in HDEEA- $p$ ABA, since the dihedral angle between the least squares plane of the phenyl ring $\mathrm{C}_{6}$ and the $\mathrm{COO}^{-}$group was equal to $20.1^{\circ}$ and $5.6^{\circ}$, respectively.

The nitrogen atoms in the amino group in both structures had almost a pyramidal configuration, its valence angles being equal to 108.07, 109.00 and $111.22^{\circ}$ in (HEEA) ${ }^{+}$of HEEA-pABA, and 108.80, 109.83 and $110.01^{\circ}$ in (HDEEA) ${ }^{+}$of HDEEA-pABA. The (HEEA) ${ }^{+}$and (HDEEA) ${ }^{+}$cations adopt the Syn-Clinal conformation with the $\mathrm{N}(2) \mathrm{CCO}(3)$ torsion angles equal to -66.90 and $-66.65^{\circ}$, respectively. The alkanolamine cations and $(p A B A)^{-}$anions were held together by two charge-assisted $\mathrm{O}-\mathrm{H} \cdots \mathrm{O}^{-}$and $\mathrm{N}^{+}-\mathrm{H} \cdots \mathrm{O}$ hydrogen bonds in HEEA- $p$ ABA as distances $\mathrm{C}-\mathrm{O}(1)$ and $\mathrm{C}-\mathrm{O}(2)$ are equal to 1.270(2) and 1.254(3) $\AA$ and one charge-assisted $\mathrm{N}^{+}-\mathrm{H}^{-\cdots} \mathrm{O}^{-}$and one classic $\mathrm{O}-\mathrm{H} \cdots \mathrm{O}$ hydrogen bonds in HDEEA- $p$ ABA with C-O(1) and C-O(2) distances equal 1.254(8) and 1.276(8) $\AA$. As a result, in both compounds, a similar $R_{2}^{2}(9)$ graph set was formed. In both structures, the $\mathrm{NH}_{2}$ group of $(p \mathrm{ABA})^{-}$anion participated 
to charge-assisted $\mathrm{N}-\mathrm{H}^{\cdots} \cdots \mathrm{O}^{-}$and classic $\mathrm{N}-\mathrm{H} \cdots \mathrm{O}$ hydrogen bonds with carboxylic oxygen atoms of adjacent $p$ ABA anions (Table 2).

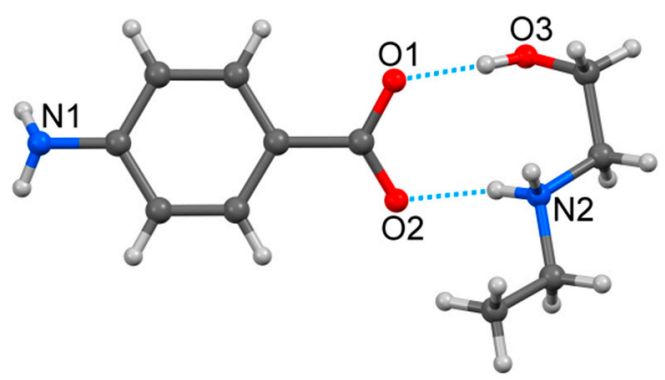

(a)

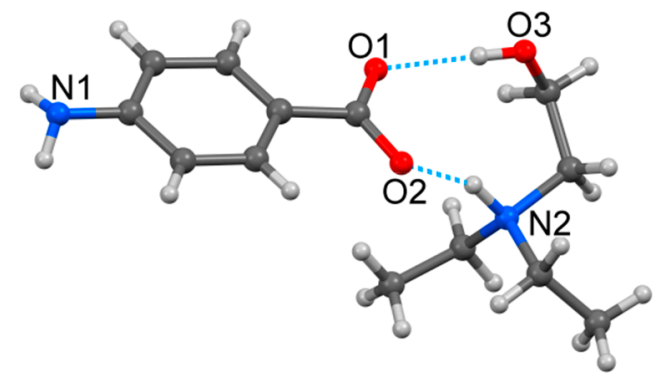

(b)

Figure 1. View of the HEEA-pABA (a) and the HDEEA-pABA (b) with partial atomic labelling and charge-assisted hydrogen bonds.

Table 1. Crystallographic data and structure refinement details for new compounds.

\begin{tabular}{|c|c|c|}
\hline Compound & HEEA- $p$ ABA & HDEEA- $p$ ABA \\
\hline Empirical formula & $\mathrm{C}_{11} \mathrm{H}_{18} \mathrm{~N}_{2} \mathrm{O}_{3}$ & $\mathrm{C}_{13} \mathrm{H}_{22} \mathrm{~N}_{2} \mathrm{O}_{3}$ \\
\hline$F w$ & 226.27 & 254.32 \\
\hline$T(\mathrm{~K})$ & 293(2) & 293(2) \\
\hline Crystal system & Monoclinic & Orthorhombic \\
\hline Space group & $P 2_{1} / c$ & $\mathrm{Pna}_{1}$ \\
\hline$a(\AA)$ & $8.3465(4)$ & 17.9492(17) \\
\hline$b(\AA)$ & $8.1802(5)$ & $11.1812(9)$ \\
\hline$c(\AA)$ & 18.8676(9) & $7.1445(6)$ \\
\hline$\beta\left(^{\circ}\right)$ & $102.684(5)$ & 90 \\
\hline$V\left(\AA^{3}\right)$ & $1256.76(11)$ & $1433.9(2)$ \\
\hline Z & 4 & 4 \\
\hline$\rho_{\text {calcd }}\left(\mathrm{g} \mathrm{cm}^{-3}\right)$ & 1.196 & 1.178 \\
\hline$\mu\left(\mathrm{mm}^{-1}\right)$ & 0.087 & 0.084 \\
\hline Crystal size (mm) & $0.60 \times 0.25 \times 0.05$ & $0.400 \times 0.200 \times 0.040$ \\
\hline $2 \Theta$ range $\left({ }^{\circ}\right)$ & 3.332 to 24.990 & 3.569 to 24.996 \\
\hline Reflections collected/unique & $4344 / 2199\left(R_{\text {int }}=0.0243\right)$ & $3177 / 1870\left(R_{\text {int }}=0.0417\right)$ \\
\hline Reflections with $(I>2 \delta(I))$ & 1576 & 1059 \\
\hline Parameters & 148 & 167 \\
\hline$R_{1}, \mathrm{w} R_{2}(I>2 \delta(I))$ & $0.0528,0.1382$ & $0.0609,0.1259$ \\
\hline$R_{1}, \mathrm{w} R_{2}$ (all data) & $0.0774,0.1564$ & $0.1147,0.1484$ \\
\hline $\mathrm{GOF}^{[\mathrm{c}]}$ & 1.000 & 1.000 \\
\hline Largest diff. peak/hole $\left(\mathrm{e} \AA^{-3}\right)$ & $0.332 /-0.306$ & $0.178 /-0.151$ \\
\hline
\end{tabular}

Cations and anions in the HEEA- $p$ ABA structure were held together in a supramolecular network (Figure 2a) obtained from $R_{2}{ }^{2}(9)$ heterosynthons (Figure $2 b$ ) and $R_{4}{ }^{4}(22)$ homosynthons formed by four anions (Figure 2c) with the involvement of fine $\mathrm{C}-\mathrm{H} \cdots \mathrm{O}$ hydrogen bond between amine and carboxylic groups (Table 2), in addition to the mentioned $\mathrm{N}(\mathrm{O})-\mathrm{H} \cdots \mathrm{O}$ hydrogen interaction. 
Table 2. Hydrogen bond distances $(\AA)$ and angles $\left(^{\circ}\right)$ in HEEA-pABA and HDEEA-pABA.

\begin{tabular}{cccccc}
\hline D-H $\cdots \mathbf{A}$ & $\mathbf{d}(\mathbf{D}-\mathbf{H})$ & $\mathbf{d}(\mathbf{H} \cdots \mathbf{A})$ & $\mathbf{d}(\mathbf{D} \cdots \mathbf{A})$ & $\angle$ (DHA) & $\begin{array}{c}\text { Symmetry Transformations for } \\
\text { Acceptor }\end{array}$ \\
\hline \multicolumn{5}{c}{ HEEA-p $\mathbf{p B A}$} \\
\hline $\mathrm{O}(3)-\mathrm{H}(1) \cdots \mathrm{O}(1)$ & 0.82 & 1.83 & $2.650(2)$ & 178 & $x, y, z$ \\
$\mathrm{~N}(1)-\mathrm{H}(1) \cdots \mathrm{O}(3)$ & 0.87 & 2.27 & $3.077(3)$ & 155 & $-x+1, y+1 / 2,-z+1 / 2$ \\
$\mathrm{~N}(1)-\mathrm{H}(2) \cdots \mathrm{O}(2)$ & 0.87 & 2.34 & $3.010(3)$ & 135 & $-x, y+1 / 2,-z+1 / 2$ \\
$\mathrm{~N}(2)-\mathrm{H}(1) \cdots \mathrm{O}(1)$ & 0.89 & 1.89 & $2.775(2)$ & 174 & $-x+1,-y+1,-z+1$ \\
$\mathrm{~N}(2)-\mathrm{H}(2) \cdots \mathrm{O}(2)$ & 0.89 & 1.92 & $2.787(2)$ & 165 & $x, y, z$ \\
$\mathrm{C}(8)-\mathrm{H}(8) \cdots \mathrm{O}(3)$ & 0.97 & 2.62 & $3.508(3)$ & 152 & $-x+1,-y,-z+1$ \\
\hline & \multicolumn{5}{c}{ HDEEA-pABA } \\
\hline $\mathrm{O}(3)-\mathrm{H}(3) \cdots \mathrm{O}(1)$ & 0.82 & 1.87 & $2.676(5)$ & 170 & $x, y, z$ \\
$\mathrm{~N}(1)-\mathrm{H}(1) \cdots \mathrm{O}(2)$ & 0.87 & 2.09 & $2.908(8)$ & 158 & $-x+3 / 2, y+1 / 2, z+1 / 2$ \\
$\mathrm{~N}(1)-\mathrm{H}(2) \cdots \mathrm{O}(1)$ & 0.87 & 2.29 & $2.858(9)$ & 123 & $-x+3 / 2, y+1 / 2, z-1 / 2$ \\
$\mathrm{~N}(2)-\mathrm{H}(2) \cdots \mathrm{O}(2)$ & 0.98 & 1.78 & $2.701(6)$ & 156 & $x, y, z$ \\
$\mathrm{C}(8)-\mathrm{H}(8) \cdots \mathrm{O}(3)$ & 0.97 & 2.54 & $3.501(9)$ & 172 & $-x+1,-y+1, z-1 / 2$ \\
$\mathrm{C}(13)-\mathrm{H}(8) \cdots \mathrm{O}(2)$ & 0.96 & 2.60 & $3.285(8)$ & 129 & $x, y, z$ \\
\hline
\end{tabular}

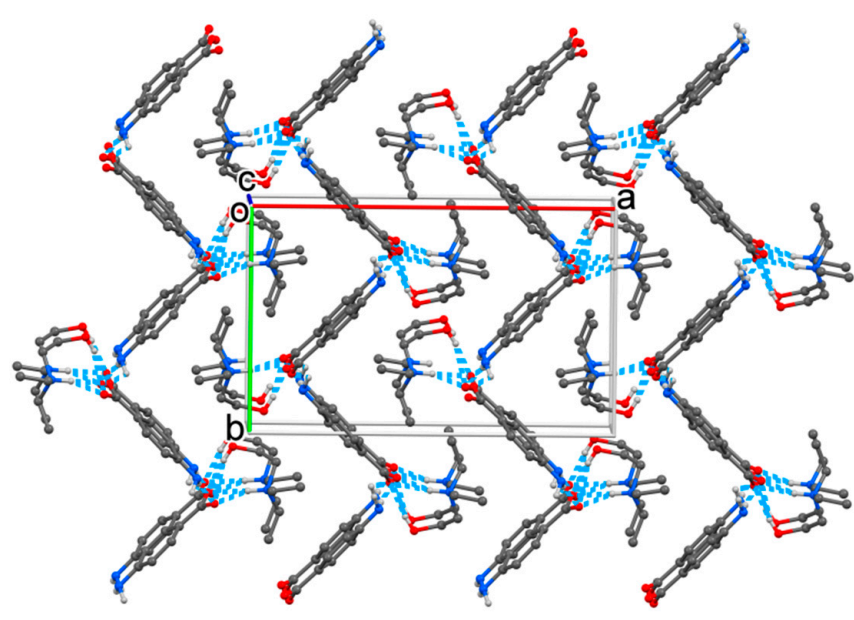

(a)

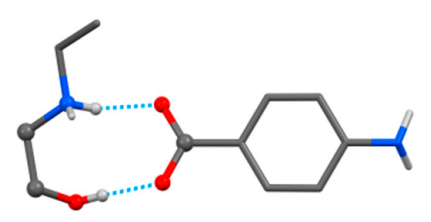

(b)

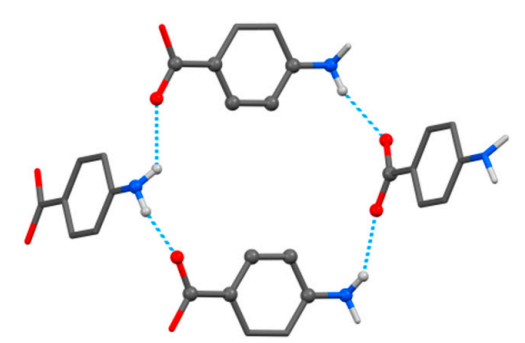

(c)

Figure 2. The crystal packing of HEEA-pABA (a) with representation of $R_{2}{ }^{2}(9)$ heterosynthon (b) and $R_{4}{ }^{4}(22)$ homosynthon in crystal (c).

The crystal packing of HDEEA-pABA (Figure 3a) was based on seven heterosynthons between HDEEA cations and $p \mathrm{ABA}$ anions: bicomponent $R_{2}{ }^{2}(9)$ heterosynthon discussed above, three tetracomponent heterosynthons formed by two cations and two anions (Figure $3 b-d$ ) and three hexacomponent heterosynthons assembled by two cations and four anions (Figure $3 \mathrm{e}-\mathrm{g}$ ). The crystalline structure was additionally stabilized by fine $\mathrm{C}-\mathrm{H} \cdots \mathrm{O}$ hydrogen bonds with the involvement of $\mathrm{C}(8)$ and $\mathrm{C}(13)$ as donors of $\mathrm{H}$ (Table 2). 


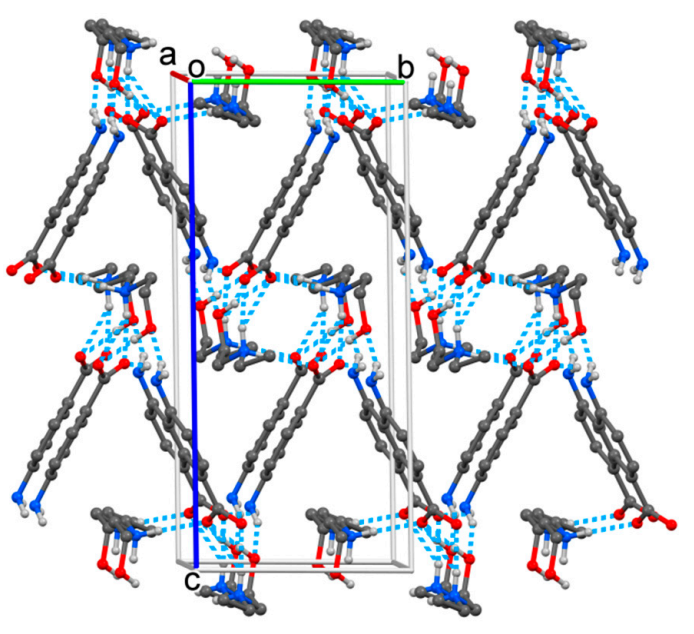

(a)

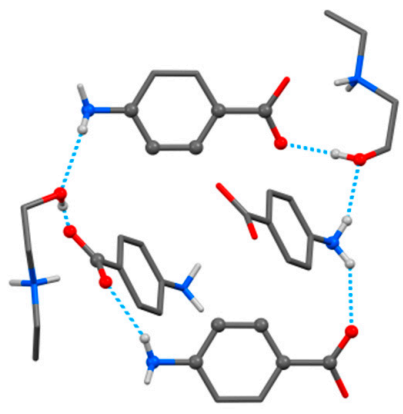

(e)

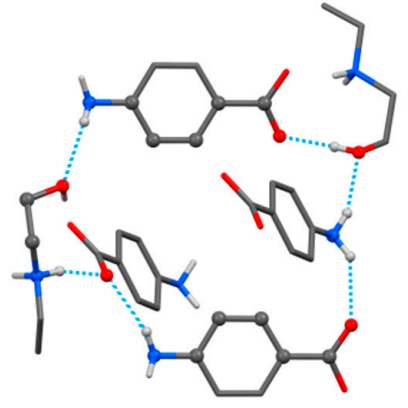

(f)

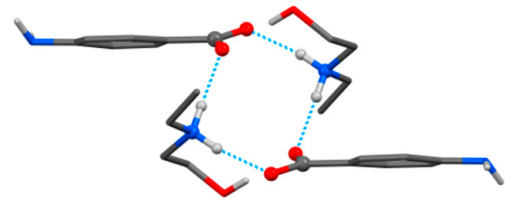

(b)

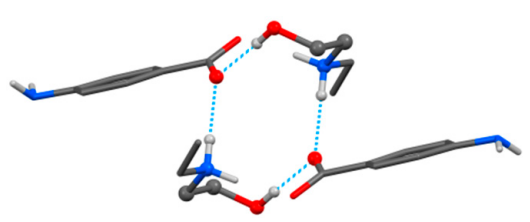

(c)

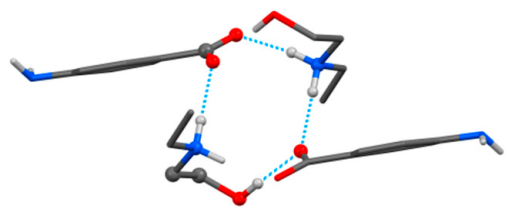

(d)

Figure 3. The crystal packing (a) and multicomponent heterosynthons found in HDEEA-pABA crystal: $R_{4}^{4}(12)(\mathbf{b}), R_{2}{ }^{4}(14)(\mathbf{c}), R_{3}{ }^{4}(13)(\mathbf{d}), R_{6}{ }^{6}(26)(\mathbf{e}), R_{5}{ }^{6}(27)(\mathbf{f})$ and $R_{5}{ }^{6}(30)(\mathrm{g})$.

\subsection{FTIR Spectroscopy}

The FTIR spectroscopic investigations (Figure 4) provide a supplementary insight into alkanolammonium salts formation by exhibiting the differences in the intensities and wavenumbers of $\mathrm{C}=\mathrm{O}, \mathrm{N}-\mathrm{H}$ and $\mathrm{O}-\mathrm{H}$ stretching modes in new compounds compared to the corresponding acid.

The HEEA-pABA and HDEEA-pABA spectra had certain similarities: the presence of strong bands responsible for the symmetric $\left(1378 \mathrm{~cm}^{-1} ; 1381 \mathrm{~cm}^{-1}\right)$ and asymmetric $\left(1602 \mathrm{~cm}^{-1} ; 1599 \mathrm{~cm}^{-1}\right)$ stretching vibrations of carboxylate group which do not exist in the spectra of $p \mathrm{ABAH}$, as well as the absence of $v \mathrm{C}=\mathrm{O}\left(1671 \mathrm{~cm}^{-1}\right), v \mathrm{C}-\mathrm{OH}\left(1287 \mathrm{~cm}^{-1}\right)$ and $\delta \mathrm{OH}\left(1417 \mathrm{~cm}^{-1}\right)$ bands characteristic of the carboxylic group [29]. The lower values for symmetric and asymmetric $v \mathrm{COO}^{-}$stretching vibrations compared to the free acid indicate that carbonyl was H-bonded in the anion-cation and anion-anion systems. Furthermore, the absence of bands characteristic of the - $\mathrm{COOH}$ group confirmed the formation of HEEA- $p$ ABA and HDEEA-pABA salts.

The strong and narrow absorption bands $\left(3464 \mathrm{~cm}^{-1}\right.$ and $\left.3360 \mathrm{~cm}^{-1}\right)$ assigned for asymmetric and symmetric $\mathrm{NH}_{2}$ stretching vibrations in $p \mathrm{ABAH}$ spectrum decreased in intensity, and wavenumbers in the case of two alkanolammonium salts, becoming $3425 \mathrm{~cm}^{-1}$ and $3341 \mathrm{~cm}^{-1}$ for HEEA-pABA and 3367 $\mathrm{cm}^{-1}$ for HDEEA- $p$ ABA. These indicate $\mathrm{N}-\mathrm{H} \cdots \mathrm{O}^{-}$and $\mathrm{N}-\mathrm{H} \cdots \mathrm{O}$ intermolecular interactions between 
anion-anion in HEEA-pABA and anion-anion/anion-cation in HDEEA-pABA. The broad bands in the range $3200-2700 \mathrm{~cm}^{-1}$ are attributed to $\mathrm{O}-\mathrm{H}$ stretching vibrations and overlap with $\mathrm{NH}_{2}{ }^{+}$vibration band $\left(3043 \mathrm{~cm}^{-1}\right)$ in the case of secondary alkanolamine. Weak bands of $\mathrm{N}-\mathrm{H}$ deformation vibrations were observed at $1640 \mathrm{~cm}^{-1}$ and $1655 \mathrm{~cm}^{-1}$, respectively, in salt spectra. Supplementary proof of the salt formation was confirmed by the appearance in HEEA- $p$ ABA and HDEEA- $p$ ABA spectra of C-O stretching vibrations at $1100-1000 \mathrm{~cm}^{-1}$, belonging to alkanolamines. The differences between two new alkanolammonium salts spectra also illustrate the diversity of the synthons in crystals.

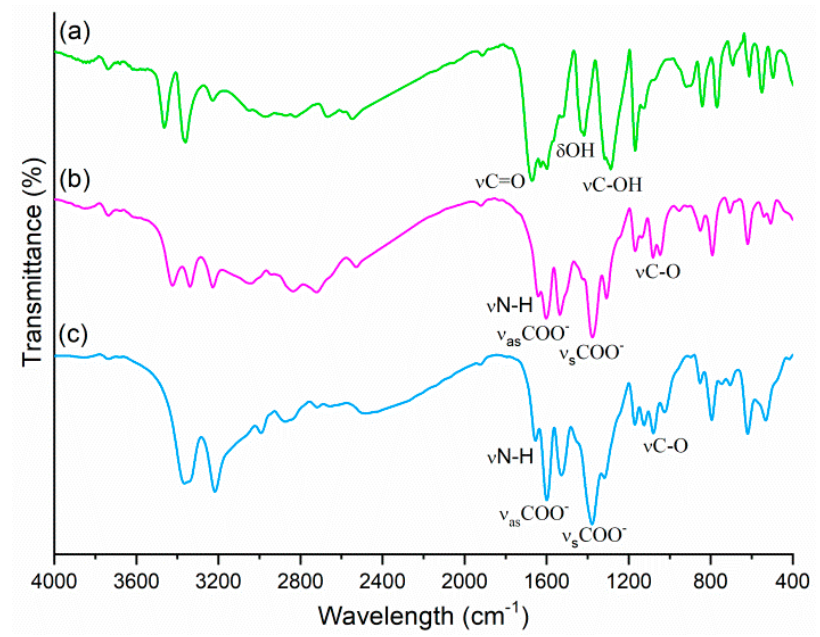

Figure 4. FTIR spectra of $p \operatorname{ABAH}(\mathbf{a}), \operatorname{HEEA}-p \operatorname{ABA}(\mathbf{b})$ and HDEEA- $p$ ABA (c).

\subsection{Thermal Analysis}

The salts were characterized by thermal analysis (thermogravimetric analysis-TGA; derivative thermogravimetry-DTG; and heat flow-HF) in order to determine thermal stability (Figure 5). The TGA and DTG curves show that HEEA-pABA and HDEEA- $p$ ABA are thermally stable up to $124{ }^{\circ} \mathrm{C}$ and $90^{\circ} \mathrm{C}$, respectively when they begin to decompose into two steps with a total mass loss of over $99.4 \%$.

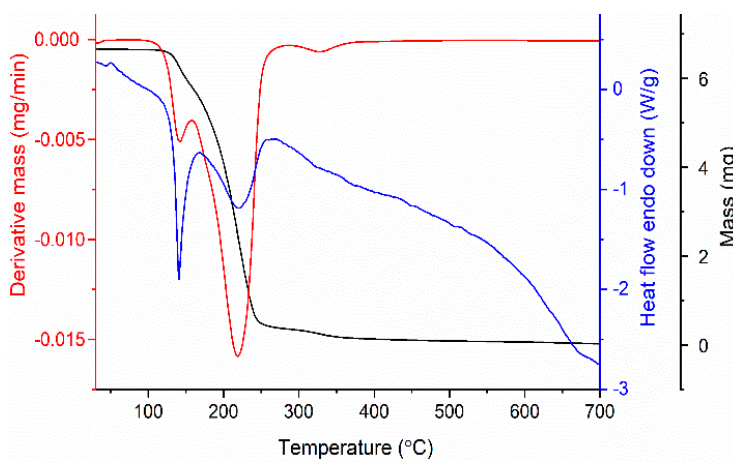

(a)

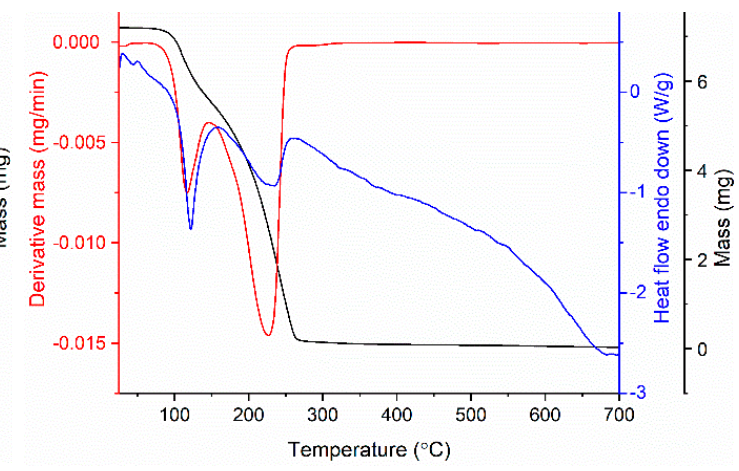

(b)

Figure 5. Thermo-analytical curves of HEEA- $p$ ABA (a) and HDEEA- $p$ ABA (b).

Therefore, HEEA-pABA had a first mass loss of $13.1 \%$ in the range $124.77^{\circ} \mathrm{C}-160.15^{\circ} \mathrm{C}$, probably due to the removal of the ethyl group from the cation. This decomposition process was accompanied by melting at $138.52{ }^{\circ} \mathrm{C}$. The second step up to $700{ }^{\circ} \mathrm{C}$ corresponded to $81.68 \%$ mass loss and complete decomposition of the compound. In the case of HDEEA-pABA, the decomposition process, up to $700{ }^{\circ} \mathrm{C}$, began with a $22.59 \%$ mass loss due to the elimination of diethyl groups from the cation and continued with the second step which involved a final $76.25 \%$ mass loss ascribed to the $\mathrm{C}_{9} \mathrm{H}_{12} \mathrm{~N}_{2} \mathrm{O}_{3}$ molecule. The DTG curve accompanied the decomposition process by one sharp peak at $115.87^{\circ} \mathrm{C}$ and another broad peak at $226.13^{\circ} \mathrm{C}$. HF curve showed a first strong and sharp endothermic peak at 
$120.85^{\circ} \mathrm{C}$, attributed to the melting point of the compound. Thermogravimetric studies indicate that the studied compounds were anhydrous and HEEA- $p$ ABA was more thermally stable than HDEEA- $p$ ABA.

\subsection{Biological Studies}

The auxin-like PGRs' effect on new compounds was investigated in laboratory and greenhouse conditions, on tomato, the main commercial vegetable cultivated in Romania and Europe in the last years. Commercial indole-3-acetic acid (IAA), the most abundant and studied natural auxin in plants, was used as the reference compound. The results of experiment 1 (Table 3 ) showed that new compounds (HEEA- $p$ ABA, HDEEA- $p$ ABA) and IAA inhibited germination at all tested concentrations or even blocking it (e.g., IAA, at concentrations above $0.5 \mathrm{mM}$ ) especially in the first interval of treatment (after 7 days), compared with the control. The results obtained show that increasing the concentration leads to inhibition of germination. Thus, in the case of HEEA- $p$ ABA application, increasing concentration from $0.1 \mathrm{mM}$ to $0.5 \mathrm{mM}$ and then to $1 \mathrm{mM}$, reduced significantly seed germination by about $20 \%$ and $9 \%$, respectively. Instead, HDEEA-pABA decreased seed germination by approximately $24.5 \%$ only from $0.5 \mathrm{mM}$ to $1 \mathrm{mM}$.

Table 3. The influence of treatments on tomato seed germination (tomato cultivar (cv.) Tomtim).

\begin{tabular}{|c|c|c|c|c|c|c|}
\hline \multirow{2}{*}{$\begin{array}{c}\text { Moment } \\
\text { Treatment }\end{array}$} & \multicolumn{3}{|c|}{ After 7 Days } & \multicolumn{3}{|c|}{ After 10 Days } \\
\hline & $0.1 \mathrm{mM}$ & $0.5 \mathrm{mM}$ & $1 \mathrm{mM}$ & $0.1 \mathrm{mM}$ & $0.5 \mathrm{mM}$ & $1 \mathrm{mM}$ \\
\hline Control (MES) & $91.11^{\mathrm{a}}$ & $91.11^{\mathrm{a}}$ & $91.11^{\mathrm{a}}$ & $100^{a}$ & $100^{a}$ & $100^{a}$ \\
\hline Indole-3-acetic acid (IAA) & $\times 8.89^{c}$ & ${ }^{x} 0^{d}$ & ${ }^{x} 0^{c}$ & $x 75.56^{b}$ & $\mathrm{y}_{0} \mathrm{~b}$ & y $0^{b}$ \\
\hline HEEA- $p$ ABA & $\mathrm{x} 46.67^{\mathrm{b}}$ & y $26.67^{c}$ & y $17.78^{b}$ & $x 88.89$ ab & $\times 93.33^{a}$ & x $91.11^{a}$ \\
\hline HDEEA- $p$ ABA & ${ }^{x} 40.00^{b}$ & $\mathrm{x} 44.44^{\mathrm{b}}$ & y $20.00^{b}$ & $\times 97.78^{a}$ & $\times 93.33^{a}$ & x $88.89^{a}$ \\
\hline \multicolumn{4}{|c|}{$\begin{array}{l}\text { Treatment. } L S D_{5 \%}=17.68(\mathrm{a}, \mathrm{b}, \mathrm{c}, \mathrm{d}) \\
\text { Concentration. } L S D_{5 \%}=11.21(\mathrm{x}, \mathrm{y})\end{array}$} & \multicolumn{3}{|c|}{$\begin{array}{l}\text { Treatment. } L S D_{5 \%}=16.64(\mathrm{a}, \mathrm{b}) \\
\text { Concentration. } L S D_{5 \%}=17.11(\mathrm{x}, \mathrm{y})\end{array}$} \\
\hline
\end{tabular}

The differences among the variants noted with different letters are considered significant $(p<0.05)$.

A tendency towards uniformization of values was revealed ten days after the induction of germination. An increase of germination with approximately $22 \%$ was observed only at the concentration of $0.1 \mathrm{mM}$, for HDEEA-pABA treatment compared to IAA. In the case of 0.5 and $1 \mathrm{mM}$ concentrations, HEEA- $p$ ABA and HDEEA- $p$ ABA treatments had similar effects; the increase of the concentration did not significantly influence seed germination. Analysis of the effects of the three treatments at the same concentration level shows that the treatments with HEEA- $p$ ABA and HDEEA-pABA had significantly higher effects than IAA on tomato seed germination.

Recent studies have characterized auxins as regulators that act positively by maintaining dormancy [30] and negatively by inhibiting seed germination [31]. The hormonal signalling of natural auxin IAA has often been associated with physiological processes manifested during plant growth and development, including seed germination [32]. Some previous studies have shown that exogenous application of IAA inhibits and delays seed germination $[33,34]$. The mechanism underlying germination blockade is not yet fully elucidated, but it seems to be due to the fact that auxin induces seminal break by enhancing signal transduction of abscisic acid, which associates auxin with maintaining seminal dormancy [30].

Therefore, the results of the tested compounds on tomato seeds germination confirm that IAA shows clear germination blocking effects, and the new compounds, even if they belong to the same category of compounds, have inhibitory effects only in the first part of the interval, the differences from the control being insignificant after a 10 day treatment.

Otherwise there are some studies that prove that besides phytohormones, there are chemical compounds that have the ability to regulate plant growth and development, such as nitrogen oxide and ROS (superoxide; hydrogen peroxide; hydroxyl radical; hydroxyl ion; and nitric oxide), both types being proven to regulate seed dormancy and germination [35-38]. 
Regarding experiment 2 (Table 4), the chlorophyll content of tomato seedlings was influenced by HEEA- $p$ ABA and HDEEA-pABA treatments, showing a significant increase compared to the control and IAA. The effect of new treatments on morphological characters in tomato seedlings indicated that plant height and primary root length presented variations comparatively with control and IAA, while maximum length of secondary roots had similar values to control and significantly smaller effect to IAA. The number of secondary roots (SR) registered the highest values under the effect of IAA treatment compared to the other treatments. The HEEA and HDEEA generated a significant increase (more than $86 \%$ of the number of SR) compared to the control.

Table 4. The influence of treatments on tomato seedlings (cv. Tomtim).

\begin{tabular}{cccccc}
\hline $\begin{array}{c}\text { Character/ } \\
\text { Treatment }\end{array}$ & Height $(\mathbf{c m})$ & $\begin{array}{c}\text { Chlorophyll } \\
\text { (SPAD) }\end{array}$ & $\begin{array}{c}\text { Primary Root } \\
\text { Length }(\mathbf{c m})\end{array}$ & $\begin{array}{c}\text { No of } \\
\text { Secondary } \\
\text { Roots }\end{array}$ & $\begin{array}{c}\text { Maximum } \\
\text { Length of } \\
\text { Secondary } \\
\text { Roots (cm) }\end{array}$ \\
\hline $\begin{array}{c}\text { Control (MES) } \\
\text { IAA }\end{array}$ & $5.50 \pm 0.50^{\mathrm{b}}$ & $31.20 \pm 1.49^{\mathrm{c}}$ & $11.10 \pm 0.37^{\mathrm{ab}}$ & $25.00 \pm 2.99^{\mathrm{c}}$ & $9.27 \pm 0.32^{\mathrm{a}}$ \\
HEEA- $p$ ABA $_{\text {HDEEA- } p \text { ABA }}$ & $5.20 \pm 0.18^{\mathrm{c}}$ & $32.25 \pm 0.25^{\mathrm{c}}$ & $8.65 \pm 0.55^{\mathrm{c}}$ & $104.50 \pm 18.42^{\mathrm{a}}$ & $3.50 \pm 0.55^{\mathrm{b}}$ \\
\hline$L S D_{5} \%$ & $6.25 \pm 0.95^{\mathrm{a}}$ & $38.20 \pm 0.60^{\mathrm{a}}$ & $11.50 \pm 0.50^{\mathrm{a}}$ & $46.50 \pm 8.47^{\mathrm{b}}$ & $8.28 \pm 0.43^{\mathrm{a}}$ \\
\hline
\end{tabular}

The differences among the variants noted with different letters are considered significant $(p<0.05)$.

It is known that auxin plays an important role in controlling the roots growth and plant development. The total amount of this major phytohormone is generated by the local biosynthesis and transport. The natural auxin IAA reveals an inhibitory effect on primary root (PR) growth. SR are essential components of the root system which contribute to maximizing the absorption capacity of water and nutrients, facilitating rapid adaptation to environmental changes $[39,40]$. It is well known that IAA is involved in each stage of SR's formation, the disorders in auxin biosynthesis and transport resulting in a reduced number of SR [41-45].

Therefore, our results attest that HEEA- $p$ ABA and HDEEA- $p$ ABA treatment solutions stimulate the plants height and the length growth of PR in contrast to IAA, which has inhibitory effects. Also, new compounds promote the formation of a large number of SR and support their growth, compared to control. Contrary, exogenous IAA generates the formation of a large number of SR (104.5 \pm 18.42$)$, probably due to the ability of acropetal migration within the root [46], but without ensuring their length growth. These results can also be correlated with the higher capacity of chlorophyll biosynthesis in variants treated with $0.5 \mathrm{mM}$ HEEA-pABA and HDEEA-pABA exogenous solutions.

The dynamics of the plants height (Table 5) shows that the foliar treatments with HDEEA- $p$ ABA and IAA have a similar and significantly superior influences to the treatments with HEEA-pABA and control, in all the stages of development, from the beginning of flowering until the first stage of fruit emergence.

Table 5. The treatments effect on height $(\mathrm{cm})$ of tomato plants (cv. Tomtim) in different stages of development.

\begin{tabular}{cccc}
\hline $\begin{array}{c}\text { Development Stage/ } \\
\text { Treatments }\end{array}$ & Beginning of Flowering & Flowering & $\begin{array}{c}\text { Emergence of First } \\
\text { Fruiting Floor }\end{array}$ \\
\hline Control (MES) & $\mathrm{z} 42.50 \pm 3.07^{\mathrm{b}}$ & $\mathrm{z} 66.75 \pm 5.02^{\mathrm{b}}$ & $\mathrm{yz} 83.75 \pm 7.53^{\mathrm{b}}$ \\
IAA & $\mathrm{z} 49.00 \pm 0.58^{\mathrm{a}}$ & $\mathrm{z} 77.00 \pm 2.89^{\mathrm{a}}$ & $\mathrm{yz} 96.67 \pm 3.67^{\mathrm{a}}$ \\
HEEA- $p$ ABA & $\mathrm{z} 43.00 \pm 4.51^{\mathrm{b}}$ & $\mathrm{z} 64.67 \pm 4.67^{\mathrm{b}}$ & $\mathrm{yz} 85.67 \pm 7.85^{\mathrm{b}}$ \\
HDEEA- $p$ ABA & $\mathrm{x} 47.00 \pm 1.00^{\mathrm{a}}$ & $\mathrm{zx} 79.67 \pm 1.20^{\mathrm{a}}$ & $\mathrm{yz} 104.33 \pm 3.39^{\mathrm{a}}$ \\
\hline
\end{tabular}

Treatments $L S D_{5 \%}=4,36(\mathrm{a}, \mathrm{b})$; developmental stage $L S D_{5 \%}=48.87(\mathrm{x}, \mathrm{y}, \mathrm{z})$. The differences among the variants noted with different letters are considered significant $(p<0.05)$. 
The three treatments and control did not differ significantly in their effect on the number of leaves at the beginning of flowering (Table 6). Significantly higher number of leaves compared to control has been stimulated by IAA during the flowering period and by HDEEA- $p$ ABA treatment at the emergence of first fruiting floor of tomato plants. All treatments presented a significant increase in the number of leaves from the beginning of flowering to full flowering, with differences between 3.33 in HEEA- $p$ ABA and 5.33 in HDEEA-pABA. In the period from flowering to the emergence of first fruiting floor, the number of leaves per plant showed little and no significant variations in all cases.

Table 6. The influence of treatments on leaves number of tomato plants (cv. Tomtim) in different stages of development.

\begin{tabular}{cccc}
\hline $\begin{array}{c}\text { Development Stage/ } \\
\text { Treatments }\end{array}$ & Beginning of Flowering & Flowering & $\begin{array}{c}\text { Emergence of First } \\
\text { Fruiting Floor }\end{array}$ \\
\hline Control (MES) & $\mathrm{y} 6.50 \pm 0.50^{\mathrm{a}}$ & $\mathrm{x} 10.50 \pm 0.87^{\mathrm{b}}$ & $\mathrm{x} 12.75 \pm 0.48^{\mathrm{b}}$ \\
IAA & $\mathrm{y} 7.33 \pm 0.67^{\mathrm{a}}$ & $\mathrm{x} 12.33 \pm 0.67^{\mathrm{a}}$ & $\mathrm{x} 13.67 \pm 0.88^{\mathrm{ab}}$ \\
HEEA- $p$ ABA & $\mathrm{y} 7.33 \pm 0.33^{\mathrm{a}}$ & $\mathrm{x} 10.67 \pm 1.45^{\mathrm{b}}$ & $\mathrm{x} 13.33 \pm 0.88^{\mathrm{ab}}$ \\
HDEEA- $p$ ABA & $\mathrm{y} 6.67 \pm 0.88^{\mathrm{a}}$ & $\mathrm{x} 12.00 \pm 1.00^{\mathrm{ab}}$ & $\mathrm{x} 14.33 \pm 0.67^{\mathrm{a}}$ \\
\hline
\end{tabular}

Treatments $L S D 5 \%=1.54(\mathrm{a}, \mathrm{b})$; Developmental stage $L S D 5 \%=3.24(\mathrm{x}, \mathrm{y})$. The differences among the variants noted with different letters are considered significant $(p<0.05)$.

It is known that auxins can stimulate plant growth by enhancing photosynthesis due to the fact of chlorophyll increases [47]. The chlorophyll pigments are probably the most relevant natural biomolecules due to the fact of their importance in photosynthesis. Therefore, a direct correlation between their quantity and gross primary productivity has been demonstrated [48]. Our results present a significant increase in chlorophyll content induced by HDEEA-pABA $(41.43 \pm 0.69)$ and a significantly lower one for HEEA-pABA $(37.07 \pm 1.74)$ compared to IAA treatment and control, at the beginning of flowering (Table 7). In the flowering and emergence of first fruiting floor periods, the highest chlorophyll content was determined in the tomato plants treated with HDEEA- $p$ ABA and IAA, respectively, while in the variants HEEA-pABA and control, the chlorophyll content was lower. Control plants recorded a significant increase of chlorophyll content from the beginning of flowering to the emergence of first fruiting floor, in contrast to treated plants, which showed a notable increase only between the first two phenophases.

Table 7. Effect of treatments on chlorophyll content (SPAD) of tomato plants' foliar apparatus (cv. Tomtim) in different stages of development.

\begin{tabular}{cccc}
\hline $\begin{array}{c}\text { Development Stage/ } \\
\text { Treatments }\end{array}$ & Beginning of Flowering & Flowering & $\begin{array}{c}\text { Emergence of First } \\
\text { Fruiting Floor }\end{array}$ \\
\hline Control (MES) & $\mathrm{u} 39.13 \pm 1.43^{\mathrm{b}}$ & $\mathrm{z} 47.00 \pm 2.14^{\mathrm{b}}$ & $\mathrm{yz} 48.75 \pm 0.70^{\mathrm{b}}$ \\
IAA & $\mathrm{y} 39.33 \pm 1.53^{\mathrm{b}}$ & $\mathrm{x} 51.50 \pm 1.45^{\mathrm{a}}$ & $\mathrm{x} 50.73 \pm 0.69^{\mathrm{a}}$ \\
HEEA- $p$ ABA & $\mathrm{z} 37.07 \pm 1.74^{\mathrm{c}}$ & $\mathrm{y} 47.43 \pm 2.38^{\mathrm{b}}$ & $\mathrm{y} 49.30 \pm 1.46^{\mathrm{b}}$ \\
HDEEA-pABA & $\mathrm{y} 41.43 \pm 0.69^{\mathrm{a}}$ & $\mathrm{x} 50.37 \pm 0.03^{\mathrm{a}}$ & $\mathrm{x} 51.17 \pm 0.23^{\mathrm{a}}$ \\
\hline
\end{tabular}

Treatments $L S D_{5 \%}=0.64(\mathrm{a}, \mathrm{b}, \mathrm{c})$; developmental stage $L S D_{5 \%}=6.73(\mathrm{u}, \mathrm{x}, \mathrm{y}, \mathrm{z})$. The differences among the variants noted with different letters are considered significant $(p<0.05)$.

These results support the hypothesis that the initiation of the flowering and fruiting processes, which means the passage of plants from the vegetative to the generative stage, diminishes or stagnates the dynamics of chlorophyll biosynthesis, the plant concentrating the metabolic activity towards the biosynthesis of photosynthetic compounds such as carbohydrates. Therefore, the cellular metabolism was modified by reducing the biosynthesis of functional molecules, with nitrogen, and stimulating the synthesis of structural biomolecules, with carbon [49].

There are studies which show that foliar application of auxinic compounds, at different concentrations, induced increases in plant height, fresh and dried mass, number of shoots and 
leaves per plant, as well as productivity-related components [50,51]. Other research, on the contrary, concluded that the application of low or moderate doses of exogenous auxins did not generate significant changes on the plant growth parameters and the high doses even had effects of reducing the values of these parameters compared to the untreated variants [52-55].

The foliar apparatus, or the number of leaves per plant, is the essential component of the photosynthetic process. The leaves are considered the primary photosynthetic organs, and their number, along with their surface, determines the amplitude of the assimilation process. Previous studies have shown that phytohormones, especially auxin (IAA) and gibberellins (GA), play a key role in the emergence and development of foliar apparatus [56]. The results prove the stimulatory effect of foliar auxin application in tomatoes plant growth, the best results being obtained by using HDEEA-pABA and IAA, respectively, at a $0.5 \mathrm{mM}$ concentration. Plants with a large number of leaves show an increased photosynthetic potential, which allows the synthesis, transport, and accumulation of larger amounts of valuable bioactive compounds [57,58].

\section{Materials and Methods}

\subsection{Materials and Physical Measurements}

Reagents $p$ ABAH, EEA (ethylethanolamine) and DEEA (diethylethanolamine) were purchased from Fluka Chemie AG (Buchs SG, Switzerland)) in analytical purity and were used without further purification. Melting points of recrystallized compounds were determined on a Boetius melting point apparatus and were uncorrected. The FTIR spectra (KBr pellet) were recorded on a JASCO-FTIR-4200 spectrometer (Easton, MD, USA), in the range $4000-400 \mathrm{~cm}^{-1}$ with a resolution of $4.0 \mathrm{~cm}^{-1}$ and a scanning speed of $16 \mathrm{~mm} \mathrm{~s}^{-1}$. Thermal analysis was performed using a TGA/SDTA 851-LF 1100 Mettler apparatus (Columbus, OH, USA) The sample weight of about $7 \mathrm{mg}$ was used for the test. The measurements were carried out in a dynamic air atmosphere, in the temperature range of $25-700{ }^{\circ} \mathrm{C}$ with a heating rate of $10^{\circ} \mathrm{C} \mathrm{min}^{-1}$.

\subsection{Synthesis Procedure of HEEA-pABA and HDEEA-pABA}

New compounds were prepared in a 1:1 molar ratio, adding dropwise EEA $(0.71 \mathrm{~mL}, 7.28 \mathrm{mmol})$ and DEEA $(0.97 \mathrm{~mL}, 7.3 \mathrm{mmol})$ respectively into a solution of $p$ ABA $(1 \mathrm{~g}, 7.29 \mathrm{mmol})$ in acetone $(20 \mathrm{~mL})$, under constant stirring at room temperature. White microcrystalline precipitates in high yields $(>95 \%)$ were formed after the addition of alkanolamines. The compounds were collected by filtration, washed with acetone, and dried in air. Colourless crystals suitable for single-crystal X-ray diffraction analysis were obtained after few days by slow evaporation in acetone. Melting points (Boetius) were: HEEA- $p$ ABA m.p. $=140-141^{\circ} \mathrm{C}$ and HDEEA- $p$ ABA m.p. $=122-123^{\circ} \mathrm{C}$.

\subsection{Single Crystal X-ray Diffraction Study}

Diffraction measurements for compounds HEEA- $p$ ABA and HDEEA- $p$ ABA were carried out at room temperature on an Xcalibur E diffractometer (Abingdon, Oxfordshire, United Kingdom) equipped with a CCD area detector and a graphite monochromator utilizing $\mathrm{MoK} \alpha$ radiation. Final unit cell dimensions were obtained and refined on an entire data set. All calculations to solve the structures and to refine the proposed models were carried out with the SHELXL2014 program package [59]. All non-hydrogen atoms were refined anisotropically. Hydrogen atoms attached to carbon, nitrogen and oxygen atoms were positioned geometrically and treated as riding atoms. The X-ray data and the details of the refinement for both compounds are summarized in Table 1, and selected geometric parameters are given in Table 2. Figures 1-3 were produced using the Mercury program (Cambridge, United Kingdom) [60]. Crystallographic data of the new compounds reported herein were deposited with the Cambridge Crystallographic Data Centre (Cambridge, United Kingdom) and allocated under the deposition numbers CCDC 1989303-1989304 (Supplementary Materials). 


\subsection{Biological Assays}

Seeds of tomato cultivar named Tomtim created by BUASVM Timisoara, included in the CPVO (Community Plant Variety Office) test protocols, UPOV (The International Union for the Protection of New Varieties of Plants) and National Tests Guidelines were used in this study.

\subsubsection{Germination Tests (Experiment 1)}

Tomatoes' mature seeds were surface sterilized by keeping them in a commercial $50 \%(\mathrm{v} / \mathrm{v})$ sodium hypochlorite solution for $10 \mathrm{~min}$ and rinsed three times with distilled water before transferring them to Petri dishes. Twenty-five sterilized seeds were each placed into a $9 \mathrm{~cm}$ Petri dish containing two Whatman filter papers moistened with $5 \mathrm{~mL}$ solution of MES (2-(N-morpholino)ethanesulfonic acid) $5 \mathrm{mM}$ and $\mathrm{CaSO} 40.5 \mathrm{mM}$ (pH 6) for control and different concentrations $(0.1,0.5$ and $1 \mathrm{mM}$ ) of HEEA- $p$ ABA, HDEEA- $p$ ABA or IAA solutions for treated samples. Each experiment was repeated three times. Petri dishes of all variants (control and treated) were placed in a growth chamber at $25 \pm$ $2{ }^{\circ} \mathrm{C}, 70 \%-75 \%$ relative humidity, and $16 / 8$ light/dark conditions. The seeds with emerged radicle were counted at 7 and 10 days and percentage were calculated.

\subsubsection{Seedling Growth Tests (Experiment 2)}

Germinated seeds of each control and $0.5 \mathrm{mM}$ treated samples were transplanted into pots $(200 \mathrm{~mL})$ with peat. Two germinated seeds/pot were placed in 15 replications for each experimental variant as follows: control watered with distilled water and other variants treated with $0.5 \mathrm{mM} \mathrm{IAA,} \mathrm{HEEA-} p$ ABA and HDEEA- $p$ ABA solutions. The treatments were performed by applying the solutions in pots, at roots, $25 \mathrm{~mL}$ at intervals of 7 days. The determinations were made after 3 applications, after 21 days of growing plants in the greenhouse $\left(25 / 18{ }^{\circ} \mathrm{C}\right.$, day/night; $65 \% \mathrm{rh}$, and $12 / 12 \mathrm{light} /$ dark conditions). Parameters included seedling height $(\mathrm{cm})$, chlorophyll content (SPAD), main root length $(\mathrm{cm})$, number and maximum length of secondary roots $(\mathrm{cm})$ were determined.

\subsubsection{Tests on Tomato Plants (Experiment 3)}

After 56 days, 10 seedlings from each experimental variant were planted in the greenhouse, on a fertile soil substrate with fermented manure $(5 \mathrm{~kg} / \mathrm{sqm})$. The same experimental variants were maintained as in the case of seedling tests, being carried out three treatments with foliar application, in doses correlated with the plant sizes of $8 \mathrm{~mL} /$ plant (the first treatment), $12 \mathrm{~mL} /$ plant (2nd) and $16 \mathrm{~mL} /$ plant (third) at 7 day intervals.

\subsubsection{Data and Statistical Analysis}

In this study, ten replicates of each moment of measurement were carried out for each sample, regarding the effect of different plant growth regulator substances and concentrations. All data were expressed as means \pm standard error of the mean (SEM). Means were compared using least significant difference $(L S D)$ test. The significant differences between the sample means $(p<0.05)$ were expressed by different letters.

\section{Conclusions}

Two new binary organic salts of $p$ ABA with different alkanolamines were successfully synthesized and characterized, and their auxin-like PGRs' properties investigated in laboratory and greenhouse on Solanum lycopersicum L. by comparison with the most abundant and studied natural auxin in plants, IAA. The single crystal structures' interpretation was correlated with the FTIR spectral data showing the intermolecular interactions established within the salts. Both new structures exhibited hydrogen-bonded supramolecular network architectures obtained from: (i) $R_{2}{ }^{2}(9)$ heterosynthons and $R_{4}{ }^{4}(22)$ homosynthons in HEEA- $p$ ABA; and (ii) $R_{2}{ }^{2}(9), R_{4}{ }^{4}(12), R_{2}{ }^{4}(14)$ and $R_{3}{ }^{4}(13), R_{6}{ }^{6}(26), R_{5}{ }^{6}(27)$ and $R_{5}{ }^{6}(30)$ heterosynthons in HDEEA-pABA. The presence of $R_{2}{ }^{2}(9)$ graph set in both structures 
indicates the relevance of charge-assisted $\mathrm{N}^{+}-\mathrm{H} \cdots \mathrm{O}^{-}$hydrogen bond in the formation of salts. The results obtained by investigating the biological profile of new alkanolammonium $p$-aminobenzoates as potential PGRs reveal the possibility of their use in stimulating the rooting and growth processes of tomato seedlings, as well as the positive involvement in plant growth and chlorophyll pigment biosynthesis. Considering the distinct supramolecular synthons in the design of molecular crystals and the promising biological results, this study sheds light on the alkanolammonium $p$-aminobenzoates as potential alternatives in the search of sustainable PGRs for tomatoes.

Supplementary Materials: Cifs for title compounds are available online.

Author Contributions: M.C. and M.P. carried out synthesis, crystallization and physicochemical characterization of new compounds; L.C. and P.B. performed the diffraction measurements and the structure refinement of single crystals; R.-L.S. and I.R. carried out the biological activity; R.-M.S. performed the statistical analysis. All authors discussed and approved the final manuscript.

Funding: This work was supported by project "Ensuring Excellence in RDI Activities within USAMVBT", code 35PFE/2018, financed by the Ministry of Research and Innovation (MCI) through Program 1-Development of the national research and development system, Subprogram 1.2-Institutional Performance, Institutional Development Projects-Projects to Fund Excellence in RDI.

Acknowledgments: The authors thank for the support of the "Coriolan Drăgulescu" Institute of Chemistry Program 2, Project 2.1 and of the Institute of Applied Physics - project ANCD 20.80009.5007.15.

Conflicts of Interest: The authors declare no conflict of interest.

\section{References}

1. Song, Y. Insight into the mode of action of 2,4-dichlorophenoxyacetic acid (2,4-D) as an herbicide. J. Integr. Plant Biol. 2014, 56, 106-113. [CrossRef] [PubMed]

2. Small, C.C.; Degenhardt, D. Plant growth regulators for enhancing revegetation success in reclamation: A review. Ecol. Eng. 2018, 118, 43-51. [CrossRef]

3. George, E.F.; Hall, M.A.; De Klerk, G. Plant growth regulators I: Introduction; auxins, their analogues and inhibitors. In Plant Propagation by Tissue Culture, 3rd ed.; George, E.F., Hall, M.A., Klerk, G.J.D., Eds.; Springer: Dordrecht, The Netherlands, 2008; pp. 175-204. [CrossRef]

4. Paque, S.; Weijers, D. Q\&A: Auxin: The plant molecule that influences almost anything. BMC Biol. 2016, 14, 67-71. [CrossRef] [PubMed]

5. Ng, P.L.L.; Ferrarese, M.L.L.; Huber, D.A.; Ravagnani, A.L.S.; Ferrarese-Filho, O. Canola (Brassica napus L.) seed germination influenced by cinnamic and benzoic acids and derivatives: Effects on peroxidase. Seed Sci. Technol. 2003, 31, 39-46. [CrossRef]

6. Crisan, M.E.; Bourosh, P.; Maffei, M.E.; Forni, A.; Pieraccini, S.; Sironi, M.; Chumakov, Y.M. Synthesis, crystal structure and biological activity of 2-hydroxyethylammonium salt of p-aminobenzoic acid. PLoS ONE 2014, 9, e101892. [CrossRef]

7. Grozav, M.; Neamtiu, I.; Dorosencu, M.; Laichici, M.; Mercea, M. The synthesis of some ammonium salts of benzoic acids with etanolamine, possible plant growth stimulators. Rev. Chim. 2003, 54, 287-288.

8. Dempsey, D.A.; Klessig, D.F. How does the multifaceted plant hormone salicylic acid combat disease in plants and are similar mechanisms utilized in humans? BMC Biol. 2017, 15, 23-33. [CrossRef]

9. Senaratna, T.; Merritt, D.; Dixon, K.; Bunn, E.; Touchell, D.; Sivasithamparam, K. Benzoic acid may act as the functional group in salicylic acid and derivatives in the induction of multiple stress tolerance in plants. Plant Growth Regul. 2003, 39, 77-81. [CrossRef]

10. Basset, G.J.C.; Quinlivan, E.P.; Ravanel, S.; Rebeille, F.; Nichols, B.P.; Shinozaki, K.; Seki, M.; Adams-Phillips, L.C.; Giovannoni, J.J.; Gregory, J.F.; et al. Folate synthesis in plants: The p-aminobenzoate branch is initiated by a bifunctional PabA-PabB protein that is targeted to plastids. Proc. Natl. Acad. Sci. USA 2004, 101, 1496-1501. [CrossRef]

11. Marbois, B.; Xie, L.X.; Choi, S.; Hirano, K.; Hyman, K.; Clarke, C.F. para-Aminobenzoic acid is a precursor in Coenzyme Q6 biosynthesis in Saccharomyces cerevisiae. J. Biol. Chem. 2010, 285, 27827-27838. [CrossRef]

12. Galbinur, T.; Obolensky, A.; Berenshtein, E.; Vinokur, V.; Chowers, I.; Chevion, M.; Banin, E. Effect of para-aminobenzoic acid on the course of retinal degeneration in the rd10 mouse. J. Ocul. Pharmacol. Ther. 2009, 25, 475-482. [CrossRef] [PubMed] 
13. Richards, R.M.R.; Xing, D.K.L.; King, T.P. Activity of p-aminobenzoic acid compared with other organic acids against selected bacteria. J. Appl. Bacteriol. 1995, 78, 209-215. [CrossRef] [PubMed]

14. Vasilieva, S. Para-aminobenzoic acid inhibits a set of SOS functions in Escherichia coli K12. Mutat. Res. Genet. Toxicol. Environ. Mutagen. 2001, 496, 89-95. [CrossRef]

15. Drozd, N.N.; Makarov, V.A.; Miftakhova, N.T.; Kalugin, S.A.; Stroeva, O.G.; Akberova, S.I. Antithrombotic activity of para-aminobenzoic acid. Eksp. Klin. Farmakol. 2000, 63, 40-44. [PubMed]

16. Andreenko, G.V.; Karabasova, M.A.; Liutova, L.A.; Podorolskaia, L.V.; Serebriakova, T.N.; Sologub, A.A.; Akberova, S.I.; Stroeva, O.G. Effect of para-aminobenzoic acid on the fibrinolytic activity of blood. Dokl. Akad. Nauk 1996, 346, 268-270. [PubMed]

17. Hanson, K.M.; Gratton, E.; Bardeen, C.J. Sunscreen enhancement of UV-induced reactive oxygen species in the skin. Free Radic. Biol. Med. 2006, 41, 1205-1212. [CrossRef] [PubMed]

18. Lu, Z.; Kong, X.; Lu, Z.; Xiao, M.; Chen, M.; Zhu, L.; Shen, Y.; Hu, X.; Song, S. para-Aminobenzoic acid (PABA) synthase enhances thermotolerance of mushroom Agaricus bisporus. PLoS ONE 2014, 9, e91298. [CrossRef]

19. Song, G.C.; Choi, H.K.; Ryu, C.M. The folate precursor para-aminobenzoic acid elicits induced resistance against Cucumber mosaic virus and Xanthomonas axonopodis. Ann. Bot. 2013, 111, 925-934. [CrossRef]

20. Groom, C.R.; Bruno, I.J.; Lightfoot, M.P.; Ward, S.C. The Cambridge structural database. Acta Crystallogr. B 2016, 72, 171-179. [CrossRef]

21. Crisan, M.E.; Gorobet, A.; Siminel, A.V.; Bourosh, P.N.; Croitor, L. A new supramolecular isomer of p-aminobenzoate Zn (II) coordination polymer: Structure and photoluminescent property. Polyhedron 2019, 171, 502-507. [CrossRef]

22. Chicu, S.A.; Herrmann, K.; Berking, S. An approach to calculate the toxicity of simple organic molecules on the basis of QSAR analysis in Hydractinia echinata (Hydrozoa, Cnidaria). Quant. Struct. Act. Relat. 2000, 19, 227-236. [CrossRef]

23. Croitor, L.; Petric, M.F.; Szerb, E.I.; Vlase, G.; Bourosh, P.N.; Chumakov, Y.; Crisan, M.E. Role of 4-nitrobenzoic acid polymorphs in the crystallization process of the organic acid-base multicomponent system. CrystEngComm 2019, 21, 6038-6047. [CrossRef]

24. Crisan, M.; Vlase, G.; Plesu, N.; Petric, M.; Croitor, L.; Kravtsov, V.; Chumakov, Y.; Bouros, P.; Vlase, T. Ethylethanolammonium 4-nitrobenzoate: Synthesis, structural characterization, thermal analysis, non-isothermal kinetic investigations and corrosion inhibitor efficiency. J. Therm. Anal. Calorim. 2018, 134, 343-352. [CrossRef]

25. Crisan, M.; Halip, L.; Bourosh, P.; Chicu, S.A.; Chumakov, Y. Synthesis, structure and toxicity evaluation of ethanolamine nitro/chloronitrobenzoates: A combined experimental and theoretical study. Chem. Cent. J. 2017, 11, 129-139. [CrossRef] [PubMed]

26. Chicu, S.A.; Grozav, M.; Kurunczi, L.; Crisan, M. SAR for amine salts of carboxylic acids to Hydractinia echinata. Rev. Chim. 2008, 59, 582-587. [CrossRef]

27. Crisan, M.; Vlase, G.; Szerb, E.I.; Vlase, T. Thermal and kinetics studies of primary, secondary and tertiary alkanolammonium salts of 4-nitrobenzoic acid. J. Therm. Anal. Calorim. 2018, 132, 1409-1418. [CrossRef]

28. Cruz-Cabeza, A.J. Acid-base crystalline complexes and the pKa rule. CrystEngComm 2012, 14, $6362-6365$. [CrossRef]

29. Pavia, D.L.; Lampman, G.M.; Kriz, G.S.; Vyvyan, J.R. Introduction to Spectroscopy, 4th ed.; Brooks/Cole, Cengage Learning: Boston, MA, USA; Belmont, CA, USA, 2009; p. 80.

30. Liu, X.; Zhang, H.; Zhao, Y.; Feng, Z.; Li, Q.; Yang, H.Q.; Luan, S.; Li, J.; He, Z.H. Auxin controls seed dormancy through stimulation of abscisic acid signaling by inducing ARF-mediated ABI3 activation in Arabidopsis. Proc. Natl. Acad. Sci. USA 2013, 110, 15485-15490. [CrossRef]

31. Ye, N.; Zhu, G.; Liu, Y.; Zhang, A.; Li, Y.; Liu, R.; Shi, L.; Jia, L. Ascorbic acid and reactive oxygen species are involved in the inhibition of seed germination by Abscisic acid in rice seeds. J. Exp. Bot. 2012, 63, 1809-1822. [CrossRef]

32. Miransari, M.; Smith, D.L. Plant hormones and seed germination. Environ. Exp. Bot. 2014, 99, $110-121$. [CrossRef]

33. Shuai, H.; Meng, Y.; Luo, X.; Chen, F.; Zhou, W.; Dai, Y.; Qi, Y.; Du, J.; Yang, F.; Liu, J.; et al. Exogenous auxin represses soybean seed germination through decreasing the gibberellin/abscisic acid (GA/ABA) ratio. Sci. Rep. 2017, 7, 1-11. [CrossRef] [PubMed] 
34. Tsygankova, V.; Andrusevich, Y.; Shtompel, O.; Myroljubov, O.; Hurenko, A.; Solomyanny, R.; Mrug, G.; Frasinyuk, M.; Shablyn, O.; Brovarets, V. Study of auxin, cytokinetin and gibberellins -like activity of heterocyclic compounds derivatives of pyrimidine, pyridine, pyrazole and isoflavones. Eur. J. Biotechnol. Biosci. 2016, 4, 29-44.

35. Bethke, P.C.; Libourel, I.G.; Jones, R.L. Nitric oxide reduces seed dormancy in Arabidopsis. J. Exp. Bot. 2006, 57, 517-526. [CrossRef]

36. Oracz, K.; Karpiński, S. Phytohormones signaling pathways and ROS involvement in seed germination. Front. Plant Sci. 2016, 7, 1-6. [CrossRef] [PubMed]

37. Mittler, R. ROS are good. Trends Plant Sci. 2017, 22, 11-19. [CrossRef] [PubMed]

38. Noctor, G.; Reichheld, J.P.; Foyer, C.H. ROS related redox regulation and signaling in plants. Semin. Cell Dev. Biol. 2017, 80, 3-12. [CrossRef]

39. Dash, M.; Yordanov, Y.S.; Georgieva, T.; Tschaplinski, T.J.; Yordanova, E.; Busov, V. Poplar PtabZIP1-like enhances lateral root formation and biomass growth under drought stress. Plant J. 2017, 89, 692-705. [CrossRef]

40. Qin, H.; Huang, R. Auxin controlled by ethylene steers root development. Int. J. Mol. Sci. 2018, $19,3656$. [CrossRef]

41. Du, Y.; Scheres, B. Lateral root formation and the multiple roles of auxin. J. Exp. Bot. 2018, 69, $155-167$. [CrossRef]

42. Cai, X.T.; Xu, P.; Zhao, P.X.; Liu, R.; Yu, L.H.; Xiang, C.B. Arabidopsis ERF109 mediates cross-talk between jasmonic acid and auxin biosynthesis during lateral root formation. Nat. Commun. 2014, 5, 1-13. [CrossRef]

43. Zhou, R.; Yu, X.; Ottosen, C.O.; Rosenqvist, E.; Zhao, L.; Wang, Y.; Yu, W.; Zhao, T.; Wu, Z. Drought stress had a predominant effect over heat stress on three tomato cultivars subjected to combined stress. BMC Plant Biol. 2017, 17, 1-13. [CrossRef] [PubMed]

44. Zhang, G.; Xu, N.; Chen, H.; Wang, G.; Huang, J. OsMADS25 regulates root system development via auxin signalling in rice. Plant J. 2018, 95, 1004-1022. [CrossRef] [PubMed]

45. Jing, H.; Yang, X.; Zhang, J.; Liu, X.; Zheng, H.; Dong, G.; Nian, J.; Feng, J.; Xia, B.; Qian, Q.; et al. Peptidyl-prolyl isomerization targets rice Aux/IAAs for proteasomal degradation during auxin signalling. Nat. Commun. 2015, 6, 1-10. [CrossRef] [PubMed]

46. Reed, R.C.; Brady, S.R.; Muday, G.K. Inhibition of auxin movement from the shoot into the root inhibits lateral root development in Arabidopsis. Plant Physiol. 1998, 118, 1369-1378. [CrossRef] [PubMed]

47. Dao, G.H.; Wu, G.X.; Wang, X.X.; Zhuang, L.L.; Zhang, T.Y.; Hu, H.Y. Enhanced growth and fatty acid accumulation of microalgae Scenedesmus sp. LX1 by two types of auxin. Bioresour. Technol. 2018, 247, 561-567. [CrossRef] [PubMed]

48. Li, Y.; He, N.; Hou, J.; Xu, L.; Liu, C.; Zhang, J.; Wang, Q.; Zhang, X.; Wu, X. Factors influencing leaf chlorophyll content in natural forests at the biome scale. Front. Ecol. Evol. 2018, 6, 1-10. [CrossRef]

49. Beinsan, C.; Camen, D.; Sumalan, R.; Babau, M. Study concerning salt stress effect on leaf area dynamics and chlorophyll content in four bean local landraces from Banat area. In Proceedings of the 44th Croatian and 4th International Symposium on Agriculture, Opatija, Croatia, 16-20 February 2009; pp. 416-419.

50. El-Saeid, H.M.; Abou-Hussein, S.D.; El-Tohamy, W.A. Growth characters, yield and endogenous hormones of cowpea plants in response to IAA application. Res. J. Agric. Biol. Sci. 2010, 6, 27-31.

51. Finet, C.; Jaillais, Y. Auxology: When auxin meets plant evo-devo. Dev. Biol. 2012, 369, 19-31. [CrossRef]

52. Khalil, S.; Mandurah, H.M. Growth and metabolic changes of cowpeas plants as affected by water deficiency and indole acetic acid. J. Agron. Crop Sci. 1989, 16, 160-166. [CrossRef]

53. El-Mergawi, R.A. Sensitivity of faba bean cultivars to low glyphosate doses and the efficiency of IAA as indicator to glyphosate effects. Egypt J. Hort. 2003, 30, 197-214.

54. Gaspar, T.H.; Kevers, C.; Faivre-Rampant, O.; Crèvecour, M.; Penel, C.L.; Greppin, H.; Dommes, J. Changing concepts in plant hormone action. Vitro Cell. Dev. Biol. Plant 2003, 39, 85-106. [CrossRef]

55. Alarcón, M.V.; Salguero, J.; Lloret, P.G. Auxin modulated initiation of lateral roots is linked to pericycle cell length in maize. Front. Plant Sci. 2019, 10, 1-10. [CrossRef] [PubMed]

56. Cui, M.; Jia, B.; Liu, H.; Kan, X.; Zhang, Y.; Zhou, R.; Li, Z.; Yang, L.; Deng, D.; Yin, Z. Genetic mapping of the leaf number above the primary ear and its relationship with plant height and flowering time in maize. Front. Plant Sci. 2017, 8, 1-13. [CrossRef] [PubMed] 
57. Shaver, G.R. Mineral nutrition and leaf longevity in Ledum palustre: The role of individual nutrients and the timing of leaf mortality. Oecologia 1983, 56, 160-165. [CrossRef] [PubMed]

58. Mauro, P.R.; Agnello, M.; Distefano, M.; Sabatino, L.; san Bautista, P.A.; Leonardi, C.; Giuffrida, F. Chlorophyll fluorescence, photosynthesis and growth of tomato plants as affected by long-term oxygen root zone deprivation and grafting. Agronomy 2020, 10, 137. [CrossRef]

59. Sheldrick, G.M. Crystal structure refinement with SHELXL. Acta Cryst. 2015, C71, 3-8. [CrossRef]

60. Macrae, C.F.; Edgington, P.R.; McCabe, P.; Pidcock, E.; Shields, G.P.; Taylor, R.; Towler, M.; Streek, J. Mercury: Visualization and analysis of crystal structures. J. Appl. Crystallogr. 2006, 39, 453-457. [CrossRef]

Sample Availability: Samples of the compounds are available from the authors.

(C) 2020 by the authors. Licensee MDPI, Basel, Switzerland. This article is an open access article distributed under the terms and conditions of the Creative Commons Attribution (CC BY) license (http://creativecommons.org/licenses/by/4.0/). 